\title{
Study of MAIT Cell Activation in Viral Infections In Vivo
}

\author{
Timothy S. C. Hinks, Bonnie van Wilgenburg, Huimeng Wang, Liyen Loh, \\ Marios Koutsakos, Katherine Kedzierska, Alexandra J. Corbett, \\ and Zhenjun Chen
}

\begin{abstract}
MAIT cells are abundant, highly evolutionarily conserved innate-like lymphocytes expressing a semiinvariant $\mathrm{T}$ cell receptor (TCR), which recognizes microbially derived small intermediate molecules from the riboflavin biosynthetic pathway. However, in addition to their TCR-mediated functions they can also be activated in a TCR-independent manner via cytokines including IL-12, -15, -18, and type I interferon. Emerging data suggest that they are expanded and activated by a range of viral infections, and significantly that they can contribute to a protective anti-viral response. Here we describe methods used to investigate these anti-viral functions in vivo in murine models. To overcome the technical challenge that MAIT cells are rare in specific pathogen-free laboratory mice, we describe how pulmonary MAIT cells can be expanded using intranasal bacterial infection or a combination of synthetic MAIT cell antigen and TLR agonists. We also describe protocols for adoptive transfer of MAIT cells, methods for lung homogenization for plaque assays, and surface and intracellular cytokine staining to determine MAIT cell activation.
\end{abstract}

Key words Virus, MAIT cell, Flow cytometry, MRl-tetramer, Infection, Mouse

1 Introduction

MAIT cells are relatively recently described innate-like lymphocytes, with similarities to the invariant natural killer T (iNKT) and $\gamma \delta \mathrm{T}$ cell subsets [1-4]. They are the most abundant innate-like population in the lungs in humans [5] though relatively rare in specific pathogen-free mice [6] and show a striking evolutionary conservation between diverse species of mammals [7]. MAIT cells express a semi-invariant $\mathrm{T}$ cell receptor (TCR), which recognizes microbially derived small molecule intermediates from the riboflavin biosynthetic pathway $[1,4,8,9]$. These molecular intermediates exist only in microbes but not in mammals, and therefore constitute a signature of microbial infection. This property implicates MAIT cells in anti-bacterial host defense, and potentially also in other roles such as tissue repair [3]. However, in addition to their 
TCR-dependent functions, they can be activated in a TCR-independent manner via cytokines including IL-12, -15, -18, and type I interferon [10-12]. Emerging data suggest that they are expanded and activated by a range of human viral infections including dengue, hepatitis $\mathrm{C}$, and influenza virus [11, 13]. It was not clear from observational human studies whether this would lead to enhanced immune protection, or, conversely, contribute to immunopathology. To address this question, we conducted experimental influenza A virus challenge in vivo in mice and demonstrated that MAIT cells could contribute to a protective anti-viral response [12].

Here we describe the methods used to investigate these antiviral functions in vivo in murine models. To overcome the technical challenge that MAIT cells are rare in specific pathogen-free laboratory mice, we describe (1) how pulmonary MAIT cells can be expanded using intranasal (i.n.) bacterial infection or a combination of synthetic MAIT cell antigen and TLR agonists as well as protocols for (2) adoptive transfer of MAIT cells, (3) viral preparation and infection of mice, (4) lung homogenization, (5) surface and intracellular cytokine staining to determine MAIT cell activation, and (6) plaque assays.

\section{Materials}

\subsection{Reagents and Buffers}

1. Antibodies are specified in Tables 1-4.

2. Collagenase medium: Roswell Park Memorial Institute medium (RPMI) containing $3 \mathrm{mg} / \mathrm{mL}$ collagenase III, $5 \mu \mathrm{g} /$ $\mathrm{mL}$ DNase, and $2 \%$ fetal calf serum (FCS). Aliquots can be frozen at $-20{ }^{\circ} \mathrm{C}$.

3. Fluorescence activated flow cytometry (FACS) buffer: phosphate buffered saline (PBS), $2 \mathrm{mM}$ EDTA, $0.5 \%$ bovine serum albumin (BSA). From a $500 \mathrm{~mL}$ bottle of PBS, add $40 \mathrm{~mL}$ to a $50 \mathrm{~mL}$ falcon containing $2.5 \mathrm{~g}$ BSA powder, vortex hard, then filter sterilize back into PBS bottle using a syringe through a $0.22-\mu \mathrm{m}$ filter. Do not add azide as will be toxic to the cells.

4. Percoll (Density $1.13 \mathrm{~g} / \mathrm{mL}$ ) 40\% and $70 \%$ solutions, pre-warmed to room temperature for each use.

5. RPMI with pen/strep: RPMI containing $100 \mu \mathrm{g} / \mathrm{mL}$ streptomycin and $100 \mathrm{U} / \mathrm{mL}$ penicillin.

6. Tris-based Ammonium Chloride (TAC)-HCl, $\mathrm{pH} 7.5$ hypotonic red blood cell lysis buffer: $0.14 \mathrm{M} \mathrm{NH}_{4} \mathrm{Cl}, 0.017 \mathrm{mM}$ Tris $(\mathrm{pH} 7.5)$, then adjust $\mathrm{pH}$ to 7.2 with $\mathrm{HCl}(2 \mathrm{M})$. The solution is filter $(0.22 \mu \mathrm{m})$ sterilized and kept at room temperature. 
Table 1

Flow cytometry panel compatible with a three-laser BD Aria III flow cytometer, allowing identification and sorting of MR1-5-OP-RU-tetramer+ MAIT cells

\begin{tabular}{llll}
\hline Marker & Fluorophore & Laser & $\begin{array}{l}\text { Standard dilution if staining } \\
\text { in } \mathbf{1 5 0 0} \mu \mathrm{L} \text {, amount in } \boldsymbol{\mu L}\end{array}$ \\
\hline CD45.2 & FITC & Blue & $3.75 \mu \mathrm{L} \mathrm{1:400}$ \\
\hline 7AAD & 7AAD & Blue or Yellow/Green & $3.75 \mu \mathrm{L}$ *titrate \\
\hline CD19 & PerCpCy5.5 & Blue or Yellow/Green & $7.5 \mu \mathrm{L} \mathrm{1:200}$ \\
\hline TCR $\beta$ & APC & Red & $7.5 \mu \mathrm{L} \mathrm{1:200}$ \\
\hline MR1-5-OP-RU tetramer & BV421 & Violet & $7.5 \mu \mathrm{L} \mathrm{1:200}$ \\
\hline
\end{tabular}

Make up volume to final $720 \mu \mathrm{L}$ with FACS buffer

Table 2

Flow cytometry panel compatible with a three-laser BD Aria III flow cytometer, allowing optimal identification of MR1-5-OP-RU-tetramer+ MAIT cells using surface stains only

\begin{tabular}{llll}
\hline Marker & Fluorophore & Laser & $\begin{array}{l}\text { Standard dilution if staining } \\
\text { in } \mathbf{4 0} \boldsymbol{\mu L} \text {, amount in } \boldsymbol{\mu L}\end{array}$ \\
\hline CD45.2 (see Note 1$)$ & FITC & Blue & $1: 200,0.2$ \\
\hline TCR $\beta$ & APC & Red & $1: 200,0.2$ \\
CD19 & PerCpCy5.5 & Blue or Yellow/Green & $1: 200,0.2$ \\
\hline CD8 & PE & Blue or Yellow/Green & $1: 800,0.08$ \\
CD4 & APC Cy7 & Red & $1: 200,0.2$ \\
\hline MR1-5-OP-RU-tetramer & BV421 & Violet & $1: 200,0.2$ \\
\hline
\end{tabular}

Antibodies should be titrated by each laboratory

\section{Table 3}

Surface markers for flow cytometry panel compatible with a three-laser BD Aria III flow cytometer, allowing measurement of MR1-5-OP-RU-tetramer+ MAIT cell activation by intracellular cytokine staining

\begin{tabular}{llll}
\hline Marker & Stain & Laser & $\begin{array}{l}\text { Standard dilution if staining } \\
\text { in } \mathbf{4 0} \boldsymbol{\mu} \text {, amount in } \boldsymbol{\mu L}\end{array}$ \\
\hline TCR $\beta$ & APC & Red & $1: 200,0.25$ \\
CD19 & PerCpCy5.5 & Blue or Yellow/Green & $1: 200,0.25$ \\
MR1-5-OP-RU-tetramer & BV421 & Violet & $1: 200,0.25$ \\
\hline
\end{tabular}


Table 4

Intracellular markers for flow cytometry panel for intracellular staining

\begin{tabular}{llll}
\hline Marker & Intracellular stain (see Note 2) & Laser & $\begin{array}{l}\text { Standard dilution if staining } \\
\text { in } \mathbf{5 0} \boldsymbol{\mu L} \text {, amount in } \boldsymbol{\mu L}\end{array}$ \\
\hline IFN $\gamma$ & PE Cy7 & Blue or Yellow/Green & $1: 400,0.125$ \\
\hline TNF & PE & Blue or Yellow/Green & $1: 300,0.17$ \\
\hline IL-17 & $\begin{array}{l}\text { PE or PECy7 or APC } \\
\text { (depending on surface stains } \\
\text { used) }\end{array}$ & $\begin{array}{c}\text { Blue or Yellow/Green, } \\
\text { Red }\end{array}$ & $1: 200,0.25$ \\
\hline
\end{tabular}

7. Fixation buffer: $1 \%$ formaldehyde, $2 \%$ glucose in PBS. Fully dissolved solution is kept cold $\left(+4^{\circ} \mathrm{C}\right)$ and dark (aluminum foil wrapped) as formaldehyde is sensitive to light.

8. Media for growing MDCK cells: Dulbecco Modified Eagle Medium (DMEM) containing $2 \mathrm{mM} \mathrm{L}$-glutamine, $1 \mathrm{mM}$ MEM sodium pyruvate, $100 \mathrm{U} / \mathrm{mL}$ penicillin/streptomycin, and $10 \%$ heat-inactivated FCS.

9. Serum-free (SF) DMEM: Dulbecco Modified Eagle Medium (DMEM) containing $2 \mathrm{mM}$ L-glutamine, $1 \mathrm{mM}$ MEM sodium pyruvate, and $100 \mathrm{U} / \mathrm{mL}$ penicillin/streptomycin.

10. $2 \times$ Leibovitz's L-15 media for overlay, make $2 \times$ stock as it will be diluted 1:1 with agarose. For 1 L: Use $1 \mathrm{~L}$ sterile water. Remove $100 \mathrm{~mL}$ of the water but keep for later use. Add two $14 \mathrm{~g}$ packets of L-15 powdered media (kept at $40{ }^{\circ} \mathrm{C}$ ). Add magnetic flea and stir for $4 \mathrm{~h}$ or more to ensure the powder is completely dissolved. Adjust $\mathrm{pH}$ to 6.8 using $1 \mathrm{M} \mathrm{HCl}$. Then add the following to the medium.

(a) $8 \mathrm{~mL}$ of $7 \% \mathrm{w} / \mathrm{v} \mathrm{NaHCO}_{3}$ prepared in Hanks Buffered Saline Solution (HBSS) (stored at $4{ }^{\circ} \mathrm{C}$ ).

(b) $800 \mu \mathrm{L} 1 \mathrm{M}$ HEPES buffer ( $\mathrm{pH} 6.8$ ).

(c) $20 \mathrm{~mL}$ of $10,000 \mathrm{U} / \mathrm{mL}$ Pen/Strep.

(d) Make up the volume to $1 \mathrm{~L}$ (using the $100 \mathrm{~mL}$ previously removed) and filter sterilize. Store at $4{ }^{\circ} \mathrm{C}$. To reduce precipitation, aliquot into $50 \mathrm{~mL}$ tubes for storage.

11. $1 \mathrm{mg} / \mathrm{mL}$ trypsin: warm up trypsin powder for $30 \mathrm{~min}$ at room temperature (kept at $+4^{\circ} \mathrm{C}$ ). Weigh out $10 \mathrm{mg}$ of powder and dissolve in $10 \mathrm{~mL}$ of PBS. Filter using $0.45 \mu \mathrm{m}$ filter. Aliquot aseptically into $220 \mu \mathrm{L} /$ aliquot. Store at $-20^{\circ} \mathrm{C}$. $200 \mu \mathrm{L}$ will be added to $100 \mathrm{~mL}$ of overlay $(50 \mathrm{~mL} \mathrm{~L}-15$ and $50 \mathrm{~mL}$ agarose) for a final concentration of $2 \mu \mathrm{g} / \mathrm{mL}$ trypsin/well.

12. Salmonella: Salmonella enterica, serovar Typhimurium (attenuated strain BRD509) [14], stored at $-20{ }^{\circ} \mathrm{C}$ in Luria- 
Bertani (LB) broth with $50 \%$ glycerol, to prevent freezing at this temperature.

13. MRl-tetramers (5-OP-RU and 6-FP) are available from the NIH core tetramer facility, on application. Store in component parts at $-80{ }^{\circ} \mathrm{C}$ until ready for use, at which point small aliquots can be tetramerized and stored at $4{ }^{\circ} \mathrm{C}$ for days to weeks. They should be reconstituted according to instructions supplied with the product. Typically a $5-\mu \mathrm{g}$ aliquot of MRl-5OP-RU monomer or MRl-6-FP monomer should be expanded to a total volume of $18 \mu \mathrm{L}$ in Tris-buffered saline. About $6.8 \mu \mathrm{L}$ of commercially available streptavidin-PE at $0.5 \mathrm{mg} / \mathrm{mL}$ should be made up to a total volume of $17 \mu \mathrm{L}$ in Tris-buffered saline. Add 1/10 of the streptavidin-PE solution $(1.7 \mu \mathrm{L})$ to the monomer solution every $10 \mathrm{~min}$ and pipette to mix, incubating at room temperature in the dark between steps. Repeat until all the streptavidin-PE solution has been added. This will give a final volume of $35 \mu \mathrm{L}$ containing $0.143 \mu \mathrm{g} / \mu \mathrm{L}$ of tetramer. The tetramer should be titrated for use; typically 1:200-1:1000 dilutions are sufficient.

14. Madin-Darby Canine Kidney (MDCK) cells.

15. Live/Dead Fixable Aqua Dead Cell Stain Kit or Zombie Yellow Viability Stain Kit.

16. Brefeldin A.

17. Phorbol 12-myristate 13-acetate (PMA).

18. Ionomycin.

19. Trypsin-versene.

20. $1 \%$ Crystal Violet in $20 \%$ ethanol and $\mathrm{dH}_{2} \mathrm{O}$.

21 . Flow cytometry compensation beads.

22. Flow cytometry $6 \mu \mathrm{m}$ blank size calibration beads.

23. Fixation/permeabilization buffer and perm-wash buffer.

24. LB agar plates, containing $50 \mu \mathrm{g} / \mathrm{mL}$ streptomycin.

25. LB culture medium.

26. 2.4G2 (anti CD16/32) hybridoma cell culture supernatant.

27. Anti-CD4 (GKl.5) and anti-CD8 (53.762) monoclonal antibodies for depletion of adoptively transferred $\mathrm{T}$ cell subsets.

28. 1\% Virkon or 10\% Lysol or Hypochlorite (5000 ppm).

29. $80 \% \mathrm{w} / \mathrm{v}$ EtOH.

30. Hanks buffered saline solution (HBSS).

31. Isoflurane.

2.2 Plastic and Other Supplies
1. 1 and $10 \mathrm{~mL}$ syringes.

2. $26 \mathrm{G}$ needles. 


\subsection{Equipment}

3. Dissection scissors.

4. $1 \mathrm{~mL}$ Eppendorf tubes.

5. 40 and $70 \mu \mathrm{m}$ cell strainers.

6. $10 \mathrm{~cm}$ Petri dishes.

7. 10, 15, and $50 \mathrm{~mL}$ Falcon tubes.

8. $5 \mathrm{~mL}$ polypropylene or polycarbonate FACS tubes.

9. Flat-bottom 6-well (TC6) plates.

10. 96-well flat-bottom plates.

11. 96-well U- or V-bottom plates.

1. Flow cytometer with capability for cell sorting, BD LSR Aria or equivalent.

2. Spectrophotometer capable of reading at $600 \mathrm{~nm}$.

3. Hemocytometer and light microscope.

4. Animal anesthetic circuit capable of administering volatile inhalational anesthetics.

5. Shaking incubator.

6. Gaseous carbon dioxide and gas exposure chamber.

7. Benchtop mechanical roller for tubes.

8. Tissue homogenizer for disrupting tissue into single cell suspensions.

3 Methods

Personal protective equipment (PPE) should be worn at all times (gloves, lab coat, \& eye protection) (see Notes 3 and $\mathbf{4}$ ).

3.1 MAIT Cell Expansion in Donor Mice
MAIT cells are rare in specific pathogen-free mice [6], typically comprising about $1 \times 10^{4}$ recoverable pulmonary MAIT cells in an infection-naïve adult C57BL/6 mouse. Therefore, for adoptive transfer experiments, the MAIT cell population should first be expanded using intranasal infection [15] or immunization (5-OP-RU with TLR agonists) [3, 15] (see Note 5). When planning the adoptive transfer experiment, estimate that one $S$. Typhimurium BRD509-infected mouse will yield 1-2 $10^{6}$ sorted MAIT cells, which are enough for 10-20 recipient mice $\left(10^{5}\right.$ MAIT cells $/ \mathrm{RAG}^{-/-} \gamma \mathrm{C}^{-/-}$mouse in this case). Infect donor mice 7 days earlier than the adoptive transfer.

1. Two days before infection streak out a plate of $S$. Typhimurium BRD509 (an attenuated vaccine strain [14]) on LB agar plates, 
containing $50 \mu \mathrm{g} / \mathrm{mL}$ streptomycin and incubate plates overnight at $37^{\circ} \mathrm{C}$.

2. The day before infection, pick a single colony under flame and inoculate to $10 \mathrm{~mL} \mathrm{LB}$ culture medium with $50 \mu \mathrm{g} / \mathrm{mL}$ streptomycin and leave static at $37^{\circ} \mathrm{C}$ (double contained if working with wild type/virulent SL1344 or equivalent strains) overnight.

3. On the day of infection, re-inoculate into fresh $10 \mathrm{~mL}$ pre-warmed LB culture medium with $0.5,100$, or $20 \mu \mathrm{L}$ of overnight culture, under flame. This is to ensure an optimal optical density (O.D.) reading (bacteria in log phase growth) for preparing the inoculum later (see Note 6). The doubling time for Salmonella can vary between 0.5 and $1 \mathrm{~h}$. Make the infection inoculum from culture with O.D.600nm reading between 0.2 and 0.6. Calculate the required CFU of bacteria estimating 1 O.D. $=5-10 \times 10^{8} \mathrm{CFU}$ (this constant needs to be established for individual labs). Dilute with PBS to a final concentration of $2 \times 10^{7} \mathrm{CFU} / \mathrm{mL}$, allowing $50 \mu \mathrm{L}$ inoculum/mouse, i.e., $10^{6} \mathrm{CFU} / 50 \mu \mathrm{L} /$ mouse.

4. Infect mice i.n. with $10^{6} \mathrm{CFU} S$. Typhimurium BRD509 in $50 \mu \mathrm{L} \mathrm{PBS}$ under isoflurane anesthesia (see Notes 7 and 8 ).

5. Allow mice to recover and monitor mice for 7 days to allow the infection to take its course and MAIT cell frequencies to expand dramatically from $10^{4}$ to $5 \times 10^{6}$ MAIT cells, or from $1 \%$ to $20-50 \%$ of all alpha-beta T cells [15] (see Note 8 ).

\subsection{MAIT Cell} Adoptive Transfer
1. 7 days or more after intranasal infection with $S$. Typhimurium, MAIT cells can be harvested ( see Note 9). As MAIT cells are to be used for adoptive transfer, all procedures should be performed in a BSCII biosafety cabinet. All tools and reagents should be sterile.

2. Prewarm collagenase media and shaking incubator to $37^{\circ} \mathrm{C}$.

3. Mice should be euthanized (e.g., using a rising concentration of $\mathrm{CO}_{2}$ with a second method to confirm death).

4. Open the diaphragm by cutting the rib cage to expose both the heart and lungs. Gently perfuse the right ventricle with 8-10 mL of ice-cold RPMI to dispense circulating blood. Perfuse using a $10-\mathrm{mL}$ syringe and a $26-\mathrm{G}$ needle. Efficient perfusion will result in lung inflation and a color change to pink/white.

5. Remove lungs using scissors to cut through the hilum and place into a 24-well plate containing ice-cold RPMI to transfer organs to the laboratory.

6. Chop lungs into fine pieces (see Note 10). 
7. Place lung tissue into a $1-\mathrm{mL}$ Eppendorf tube containing 1-2 $\mathrm{mL} /$ lung of pre-warmed collagenase medium. Incubate tubes on their sides in a shaking incubator at $37{ }^{\circ} \mathrm{C}$, at 100-180 rpm, for $90 \mathrm{~min}$.

8. During this time prepare Percoll gradients and antibody cocktails (see Table 1).

9. After $90 \mathrm{~min}$ pour digested tissue through a $70-\mu \mathrm{m}$ cell strainer and force through into a Petri dish with the plunger from a 1-mL syringe. Rinse residual sample with extra FACS buffer for maximum MAIT cell yield. Cells from multiple lungs (if required) (see Note 11) are pooled into a single $50-\mathrm{mL}$ Falcon tube with a total of $50 \mathrm{~mL}$ of sterile FACS buffer.

10. Centrifuge at $400 \times g$ for $5 \mathrm{~min}$ to pellet the cells. Pour off supernatant $(\mathrm{SN})$.

11. Resuspend cells in $20 \mathrm{~mL} 40 \%$ Percoll. Underneath this layer use a transfer pipette to layer $20 \mathrm{~mL} 70 \%$ Percoll (see Note 12). Centrifuge this gradient at $800 \times g$ for $20 \mathrm{~min}$ at room temperature with the centrifuge brake OFF. Lymphocytes and other immune cells will form a visible interphase layer between the $40 \%$ and $70 \%$ Percoll post centrifugation.

12. During this centrifugation step, prepare single color controls. It is convenient to use part of a spleen forced through a $70-\mu \mathrm{m}$ filter and resuspended in $5 \mathrm{~mL}$ TAC for $5 \mathrm{~min}$ at $37^{\circ} \mathrm{C}$, then washed once with $5 \mathrm{~mL}$ FACS buffer.

13. Collect the interphase between $40 \%$ and $70 \%$ Percoll into a fresh $50 \mathrm{~mL}$ Falcon and top up with FACS buffer to a total of $50 \mathrm{~mL}$. Centrifuge at $400 \times g$ for $5 \mathrm{~min}$.

14. Pour off supernatant and resuspend in $5 \mathrm{~mL}$ FACS buffer, transferring to a $10 \mathrm{~mL}$ Falcon tube. Centrifuge at $400 \times g$ for $5 \mathrm{~min}$.

15. Resuspend all lung cells in $750 \mu \mathrm{L}$ FACS buffer.

16. Block non-specific tetramer binding by adding $7.5 \mu \mathrm{L} 2.4 \mathrm{G} 2$ (anti CDl6/32) cell culture supernatant, containing MRl-6FP tetramer $[8,16]$ (no fluorochrome, 1:100). Incubate at room temperature on a roller or bench rocker for $15 \mathrm{~min}$.

17. For lungs from 5 mice, add $750 \mu \mathrm{L}$ of staining cocktail (Table 1).

18. Cover in aluminum foil to protect fluorochromes from light and shake on roller for $30 \mathrm{~min} \mathrm{RT}$.

19. Wash with $10 \mathrm{~mL}$ of FACS wash. Centrifuge at $400 \times \mathfrak{g}$ for 5 min. Pour off supernatant.

20. Wash again with $10 \mathrm{~mL}$ of FACS wash. Centrifuge at $400 \times \mathfrak{g}$ for 5 min. Pour off supernatant. 




Fig. 1 Flow cytometry gating strategy for MR1-5-OP-RU-tetramer+ MAIT cells

21. Resuspend cells in $2 \mathrm{~mL}$ FACS wash and filter through $40 \mu \mathrm{m}$ filter into non-pyrogenic FACS tubes.

22. Sort live MAIT cells (defined as $\mathrm{CD}^{+} \mathrm{CD} 45^{+} \mathrm{MRI}-5-\mathrm{OP}-\mathrm{RU}$ tetramer $^{+}$cells) (Fig. 1) into $3 \mathrm{~mL}$ of FCS in $15 \mathrm{~mL}$ Falcon tube. For detailed gating strategy, refer to [17]. Wash cells and adjust cell concentration to $5 \times 10^{5}$ cell $/ \mathrm{mL}$, allowing $10^{5}$ in $200 \mu \mathrm{L}$ for injection to each mouse.

23. Inject $10^{5}$ cells into the tail vein of recipient mice using cells suspended in $200 \mu \mathrm{L}$ PBS in a $1-\mathrm{mL}$ syringe with a 26-G cannula after warming the mice for 5-15 min with appropriate monitoring.

24. To deplete residual non-MAIT T cells ( see Note 13), inject recipient mice on days 2 and days 5 or 6 with $0.1 \mathrm{mg}$ each of purified anti-CD4 (GKl.5) and anti-CD8 (53.762) monoclonal antibodies i.v.

25. Rest mice for a total of 2 weeks post adoptive transfer to allow MAIT cell populations to settle in the host.

3.3 Influenza A Virus Infection
1. Thaw virus vial rapidly in a $37^{\circ} \mathrm{C}$ water bath until all ice crystals have melted.

2. Decontaminate the outer surface of the vial with $70 \%$ ethanol. 
3.4 Lung Homogenization

3.5 MAIT Cell Intracellular Cytokine Staining
3. Perform serial dilutions in sterile PBS to achieve the desired inoculum. For example:

(a) If titer of PR8 stock $=1.0 \times 10^{9}$ plaque-forming units $(\mathrm{PFU}) / \mathrm{mL}$, require $25 \mathrm{PFU} /$ inoculum (see Note 14).

(b) Volume of inoculum required for intranasal infection $=50 \mu \mathrm{L} /$ inoculum.

(c) $25 \mathrm{PFU} / 50 \mu \mathrm{L}=500 \mathrm{PFU} / \mathrm{mL}$, dilution required from virus stock $\mathrm{DF}=2,000,000$.

- Dilution 1: 1/100: $10 \mu \mathrm{L}$ of virus stock $+990 \mu \mathrm{L}$ PBS.

- Dilution 2: 1/100: $10 \mu \mathrm{L}$ of dilution $1+990 \mu \mathrm{L}$ PBS.

- Dilution 3: 1/100: $10 \mu \mathrm{L}$ of dilution $2+990 \mu \mathrm{L}$ PBS.

- Dilution 4: 1/2: (depends on volume required, e.g., 20 inoculations $=1000 \mu \mathrm{L}) 500 \mu \mathrm{L}$ of dilution 3 and $500 \mu \mathrm{L}$ of PBS.

4. Mix virus with vortex before administering the inoculum.

5. Infect mice i.n. with $50 \mu \mathrm{L}$ under isoflurane anesthesia (see Note 7).

6. Allow mice to recover and monitor mice for until recovery (typically 10 days) (see Note 15).

1. Collect the lungs into $2 \mathrm{~mL}$ of RPMI supplemented with penicillin/streptomycin.

2. For homogenization, place the lung and the $2 \mathrm{~mL}$ of media into $10 \mathrm{~mL}$ falcon tubes with lids (see Note 16).

3. Prepare 10 or $15 \mathrm{~mL}$ Falcon tubes with $2 \times 5 \mathrm{~mL} 80 \% \mathrm{w} / \mathrm{v}$ EtOH for cleaning the homogenization probe initially and 1 tube containing HBSS. For each group of samples, prepare further $1 \times 5 \mathrm{~mL}$ EtOH and $1 \times 5 \mathrm{~mL} \mathrm{HBSS}$, and for the final probe clean set up $2 \times 5 \mathrm{~mL}$ of EtOH.

4. Homogenize the sample using a homogenizer, mounted on a retort stand with the probe set to medium for $30 \mathrm{~s}$ per sample. Keep samples on ice (see Note 17).

5. Centrifuge the samples at $1000 \times g$ for $7 \mathrm{~min}$.

6. Using a $1 \mathrm{~mL}$ pipette, carefully draw up approximately $1 \mathrm{~mL}$ (a little bit more is good) of supernatant, avoiding the pellet and fatty residue on top. Divide this volume into two $1.5 \mathrm{~mL}$ Eppendorf tubes. Store at $-80{ }^{\circ} \mathrm{C}$ for subsequent plaque assays.

To analyze MAIT cell frequencies and function during viral infection.

1. Prewarm collagenase media and shaking incubator to $37^{\circ} \mathrm{C}$. 
2. Mice should be euthanized (e.g., using a rising concentration of $\mathrm{CO}_{2}$ with a second method to confirm death).

3. Open the diaphragm by cutting the rib cage to expose both the heart and lungs. Gently perfuse the right ventricle with 8-10 mL of ice-cold RPMI to remove circulating blood. Perfuse using a $10-\mathrm{mL}$ syringe and a $26-\mathrm{G}$ needle. Proper perfusion will result in lung inflation and a color change to pink/ white.

4. Remove lungs ( see Note 18) using scissors to cut through the hilum and place into a 24-well plate containing ice-cold RPMI to transfer organs to the laboratory.

5. Chop lungs into very small pieces (see Note 9).

6. Place lung tissue into a $1-\mathrm{mL}$ Eppendorf tube containing $0.5 \mathrm{~mL} /$ lung of pre-warmed collagenase/DNase medium. This should also contain, $0.5 \mu \mathrm{L}$ of Brefeldin A (1:1000) (final concentration $3.0 \mu \mathrm{g} / \mathrm{mL}$ ).

7. Incubate tubes on their sides in a shaking incubator at $37^{\circ} \mathrm{C}$, at 100-180 rpm, for $90 \mathrm{~min}$.

8. After $90 \mathrm{~min}$ pour digested tissue through a 70 - $\mu \mathrm{m}$ cell strainer and force through into Petri dish with the plunger from a $1-\mathrm{mL}$ syringe. Rinse residual cells into a total of $10 \mathrm{~mL}$ FACS wash in $10 \mathrm{~mL}$ falcon tubes at RT. Centrifuge at $400 \times g$ for $5 \mathrm{~min}$ at RT.

9. Resuspend in $2 \mathrm{~mL}$ per lung (see Note 19) of pre-warmed TAC lysis buffer at $37^{\circ} \mathrm{C}$. Vortex well, then place in a pre-warmed water bath at $37^{\circ} \mathrm{C}$. After $5 \mathrm{~min}$ neutralize by adding an equal volume of FACS buffer. Centrifuge at $400 \times g$ for $5 \mathrm{~min}$, RT.

10. Numbers of lung cells can be estimated using a hemocytometer or spectrophotometer (see Notes 20 and 21).

11. Transfer $100 \mu \mathrm{L}$ containing $0.5-1$ million cells to a 96-well Uor V-bottom plate format or into FACS tubes for staining, passing them through a $40-\mu \mathrm{m}$ mesh (see Note 22).

(a) $1 \times 100 \mu \mathrm{L}$ into a plate for surface stain (steps 16-22).

(b) $2 \times 100 \mu \mathrm{L}$ (unstimulated and stimulated) to a second plate (see Note 23), and include a no Brefeldin control (steps 12, 13, and 21-30).

In vitro stimulation phase:

12. Keep the cells for the surface stain on ice, while setting up PMA/Ionomycin stimulation to induce production of cytokines of interest.

(a) PMA final concentration: $20 \mathrm{ng} / \mathrm{mL}$.

(b) Ionomycin $1 \mu \mathrm{g} / \mathrm{mL}$.

(c) $1000 \times$ stock Brefeldin A (final concentration $3.0 \mu \mathrm{g} /$ $\mathrm{mL})$. 
13. Incubate for $3 \mathrm{~h}$ at $37{ }^{\circ} \mathrm{C}$ with $5 \% \mathrm{CO}_{2}$.

Surface staining:

14. During stimulation phase perform surface staining for extracellular markers (see Note 24).

15. If performing Zombie Yellow vital staining wash cells with 1-2 mL PBS. Centrifuge at $400 \times \mathfrak{g}, 5 \mathrm{~min}$ (or if using plate format wash twice with $200 \mu \mathrm{L}$ FACS buffer centrifuging for $2 \mathrm{~min}$ at $400 \times \mathrm{g})$. Resuspend in $20 \mu \mathrm{L} \mathrm{PBS}+0.4 \mu \mathrm{L}$ Zombie Yellow for $15 \mathrm{~min}$.

16. Add $20 \mu \mathrm{L}$ of $2.4 \mathrm{G} 2$ (anti-CD16/32) containing $0.2 \mu \mathrm{L}$ of MRl-6-FP tetramer (no fluorochrome conjugate) to block non-specific binding. Incubate for 15 min dark, room temp.

17. Add surface cocktail (Table 2) using a cocktail made up in $10 \mu \mathrm{L}$ FACS buffer. Pipette carefully to mix. Stain for 20-30 $\mathrm{min}$ at room temperature.

18. For single color controls use splenocytes or compensation beads.

19. Wash cells twice with $2 \mathrm{~mL}$ FACS buffer, centrifuging at $400 \times g$ for $5 \mathrm{~min}$ (or if using plate format wash three times with $200 \mu \mathrm{L}$ FACS buffer centrifuging for $2 \mathrm{~min}$ at $400 \times g)$.

20. Resuspend cells in $100 \mu \mathrm{L}$ FACS buffer (see Note 25). To enable estimation of absolute cell numbers, add a known number of calibration beads.

(a) Vortex calibration beads hard. Dilute (1:10) counting beads in PBS before using. To each sample $25 \mu \mathrm{L}$ of these diluted beads was added, and an additional $10 \mu \mathrm{L}$ of beads were saved to be counted with a hemocytometer, giving a count of $\mathrm{X}$ in a large square, i.e., $\mathrm{X} \times 10^{4}$ beads/ $\mathrm{mL}$ (which is $\mathrm{X} \times 10$ beads $/ \mu \mathrm{L}$, or $\mathrm{X} \times 10 \times 25$ beads sample). Typically add a total of 25,000 beads per sample.

(b) When samples have been acquired on flow cytometer, these calibration beads can be detected using their FSC/SSC profile and the absolute number of cells of interest can be estimated using the following approach. Total number of MAIT cells per sample $=$ Number of MAIT cells counted on flow cytometer $\times$ Number of beads added/Number of beads counted/proportion of total lung cell suspension actually used for staining.

Intracellular staining:

21. After 3-h stimulation, continue processing the cells for intracellular staining. Resuspend into FACS tube with $+1 \mathrm{~mL}$ PBS. Centrifuge at $400 \times \mathfrak{g}, 5 \mathrm{~min}$. (Alternatively, if in 96-well format resuspend in $100 \mu \mathrm{L} \mathrm{PBS}$, centrifuge at $400 \times g$ for 2 min and repeat.) 
22. Resuspend in $20 \mu \mathrm{L}$ PBS with $0.4 \mu \mathrm{L}$ Zombie Yellow for $15 \mathrm{~min}$.

23. Add $20 \mu \mathrm{L}$ of $2.4 \mathrm{G} 2$ (anti CDl6/32) SN containing $0.2 \mu \mathrm{L}$ of unlabeled MRl-6-FP tetramer to block non-specific tetramer staining. Incubate for $15 \mathrm{~min}$ dark, room temperature.

24. Add surface cocktail (Table 3 ) using a cocktail made up in $10 \mu \mathrm{L}$ FACS buffer. Pipette carefully to mix. Stain for 20-30 min at room temperature.

25. For single color controls use splenocytes or compensation beads. These may be available from being made up earlier in the protocol.

26. Wash cells once with $1 \mathrm{~mL}$ FACS buffer, centrifuging at $400 \times g$ for $5 \mathrm{~min}$ (or if using plate format wash twice with $200 \mu \mathrm{L}$ FACS buffer centrifuging for $2 \mathrm{~min}$ at $400 \times g)$.

27. Resuspend in $200 \mu \mathrm{L}$ of commercially available Fixation/Permeabilization solution and incubate for $30 \mathrm{~min}$ on ice.

28. Wash with $2 \mathrm{~mL}$ Perm Wash (diluted 1:9 with FACS buffer). Centrifuge at $400 \times g$, 5 min (or if using plate format wash twice with $200 \mu \mathrm{L}$ Perm Wash centrifuging for $2 \mathrm{~min}$ at $400 \times g)$.

29. Resuspend in $50 \mu \mathrm{L}$ of Perm Wash containing intracellular cocktail (Table 4) and pipette carefully to mix. Incubate for $45 \mathrm{~min}$ or leave to stain overnight.

30. Wash cells with $2 \mathrm{~mL}$ Perm Wash (or if using plate format wash twice with $200 \mu \mathrm{L}$ Perm Wash centrifuging for $2 \mathrm{~min}$ at $400 \times g)$. Resuspend cells in $100 \mu \mathrm{L}$ FACS wash. If cells are in plate format use a multichannel pipette to transfer them to $1.2 \mathrm{~mL}$ "bullet" cluster tubes for acquisition, or use a plate reader attachment with the cytometer.

31. Analyze cells on flow cytometer.

\subsection{Viral Plaque Assay}

Viral plaque assays are used to determine influenza viral titers. A diluted solution of egg-adapted Influenza A viruses/lung-infected tissue homogenates are applied to a six-well tissue culture dish containing a monolayer of Madin-Darby canine kidney (MDCK) cells. The infected MDCK cells grow under a semisolid overlay medium (agar) containing trypsin. A plaque is produced when a virus particle infects a cell, replicates, and then kills the cell. This process can be repeated several times as surrounding cells can be infected by newly replicated virus and killed. When visualized by eye, plaques appear as white spots. The assay is measured in $\mathrm{PFU} / \mathrm{mL}$.

Passaging MDCK cells:

1. Warm up MDCK cell media, trypsin-versene, and PBS at $37^{\circ} \mathrm{C}$. 
2. Check the confluency of MDCK cells, aspirate the medium, add $10 \mathrm{~mL}$ of PBS, aspirate the medium, and repeat wash.

3. Discard PBS, add $2-3 \mathrm{~mL}$ of trypsin-versene (stored $-20^{\circ} \mathrm{C}$ ) to MDCK monolayers, and incubate at $37^{\circ} \mathrm{C}$ for $5 \mathrm{~min}$. After 5 min tap the flasks, and incubate for longer if required (maximum $15 \mathrm{~min}$ ).

4. In the meantime, add $15 \mathrm{~mL}$ of MDCK cell media to fresh T75 flasks.

5. Add MDCK cell media to a total volume of $10 \mathrm{~mL}$ to the trypsinized cells, and transfer cells to a 10 -mL tube.

6. Count cells using a hemocytometer.

7. Set up multiple T75 flasks with different cell densities to determine the growth pattern of MDCK cells. Generally $\sim 3-5 \times 10^{5}$ for 3-day split.

8. Incubate at $37{ }^{\circ} \mathrm{C}, 5 \% \mathrm{CO}_{2}$.

Amplification of MDCK cells for plaque assay:

9. Warm up MDCK cell media, trypsin-versene, and PBS at $37^{\circ} \mathrm{C}$.

10. Check the confluency of MDCK cells, aspirate the medium, add $10 \mathrm{~mL}$ PBS, aspirate the medium, and repeat wash.

11. Discard PBS, add $2-3 \mathrm{~mL}$ of trypsin-versene (stored $-20{ }^{\circ} \mathrm{C}$ ) to MDCK monolayers, and incubate at $37^{\circ} \mathrm{C}$ for $5 \mathrm{~min}$. After 5 min tap the flasks, and incubate for longer if required (maximum $15 \mathrm{~min})$.

12. In the meantime, add $40 \mathrm{~mL}$ of MDCK cell media to fresh T175 flasks. Set up one T175 flask of MDCK cells per $\sim 4$ plates for plaque assay. Each 6-well plate assays 3 viral dilutions (as dilutions are done in duplicate).

13. Add MDCK cell media to a total volume of $10 \mathrm{~mL}$ to trypsinized cells, and transfer cells to a $10-\mathrm{mL}$ tube.

14. Count cells using a hemocytometer.

15. Add $\sim 7-8 \times 10^{5}$ cells per T175 flask for 3-day culture.

Seeding flat-bottomed 6-well tissue culture (TC6) plates for plaque assay:

16. Warm up MDCK cell media, trypsin-versene, and PBS at $37^{\circ} \mathrm{C}$.

17. Check the confluency of MDCK cells, aspirate the medium, add $10 \mathrm{~mL}$ of PBS, aspirate the medium, and repeat the wash.

18. Discard PBS, add $5-8 \mathrm{~mL}$ of trypsin-versene $\left(-20{ }^{\circ} \mathrm{C}\right)$ to MDCK monolayers in T175 flask, incubate at $37{ }^{\circ} \mathrm{C}$ for $5 \mathrm{~min}$. After $5 \mathrm{~min}$, tap bottles, incubate for longer if required (maximum $15 \mathrm{~min}$ ). 
19. Add 17-20 mL of MDCK cell media to each flask (total $25 \mathrm{~mL}$ including 5-8 $\mathrm{mL}$ trypsin) to inhibit trypsin-versene.

20. Pool cells into one flask.

21. Count the cells, adjust the concentration to $3.3 \times 10^{5}$ cells/ $\mathrm{mL}$.

22. Add $3 \mathrm{~mL}$ of $3.3 \times 10^{5}$ cells $/ \mathrm{mL}$ to each well of TC6 plates $\left(\sim 1 \times 10^{6} /\right.$ well $)$, swirl plates gently to distribute cells evenly. Include a negative control plate.

23. Incubate cells at $37^{\circ} \mathrm{C}, 5 \% \mathrm{CO}_{2}$ overnight. Aim for monolayers to be confluent in 6-well plates for assay.

Plaque assay

24. Warm up SF-DMEM at $37^{\circ} \mathrm{C}$.

25. Prepare dilutions of samples to be titrated. This can be done in a 96-well flat-bottom plate.

26. Cells will be infected with $150 \mu \mathrm{L}$ of each dilution in duplicate, so a minimum of $300 \mu \mathrm{L}$ of each dilution is required. A 96-well flat-bottom plate can hold $\sim 350 \mu \mathrm{L} /$ well. $35 \mu \mathrm{L}$ of samples would be added to $315 \mu \mathrm{L}$ of media for a final volume of 350 ( 35 in $350=1: 10$ dilution). If a sample is to be plaqued neat, add $350 \mu \mathrm{L}$ of sample to the first well.

27. Add $315 \mu \mathrm{L}$ of SF-DMEM in each well of 96-well plate. A multichannel can be used and add 157 and $158 \mu \mathrm{L}$ (total 315) to each well.

28. Add $35 \mu \mathrm{L}$ of sample to the first well with media (tenfold dilution) and continue serial tenfold dilutions by transferring $35 \mu \mathrm{L}$ across wells, changing tips between dilutions.

29. For titration of viral stocks use dilutions from $10^{-4}$ to $10^{-6}$. $10^{-1}$ can be used as a positive control. Half-log dilutions can also be performed. For titration of mouse lung homogenates, generally:

(a) Days $1-5: 10^{-1}$ to $10^{-3}$.

(b) Days 6-10: neat to $10^{-2}$ (see Note 26).

30. Wash MDCK cells with 1-2 mL of PBS/well.

31. Infect cells with $150 \mu \mathrm{L} /$ well of the appropriate dilution, swirl gently to cover all cells and incubate at $37{ }^{\circ} \mathrm{C}, 5 \% \mathrm{CO}_{2}$ for $60 \mathrm{~min}$, shake gently every $15 \mathrm{~min}$.

32. In the meantime, prepare overlay media, best to start doing so in the beginning of the $1 \mathrm{~h}$ incubation of MDCK cells.

33. Weigh out $1.8 \mathrm{~g}$ of agarose into $200 \mathrm{~mL}$ glass bottle, add $100 \mathrm{~mL}$ of sterile water (1.8\% agarose), and melt in microwave. Store in a $55^{\circ} \mathrm{C}$ water bath.

34. Aliquot $50 \mathrm{~mL}$ of $2 \times \mathrm{L}-15$ medium into $50 \mathrm{~mL}$ tubes (need $2 \times 50 \mathrm{~mL}$ aliquots of $2 \times \mathrm{L}-15$ medium and 1 bottle $(100 \mathrm{~mL})$ of $1.8 \%$ agarose) and store in $37^{\circ} \mathrm{C}$ water bath. 
35. Thaw trypsin-versene at $40{ }^{\circ} \mathrm{C}$. Thaw a $200 \mu \mathrm{L}$ aliquot $/ 50 \mathrm{~mL}$ of $2 \times \mathrm{L}-15$.

36. After $1 \mathrm{~h}$ incubation of MDCK cells with sample: Add $200 \mu \mathrm{L}$ trypsin to each $50 \mathrm{~mL}$ tube of $2 \times \mathrm{L}-15$.

37. Make overlay media by adding $100 \mathrm{~mL}$ of $2 \times \mathrm{L}-15+$ trypsin solution to $100 \mathrm{~mL}$ of $1.8 \%$ agarose and mix well (see Note 27).

38. Add $3 \mathrm{~mL}$ of overlay medium/well and leave at RT until it sets.

39. Incubate upside-down at $37{ }^{\circ} \mathrm{C}, 5 \% \mathrm{CO}_{2}$ for 3 days. Plaques maybe visible by the end of day 2 and the plates can be incubated till day 4 if plaques are too small on day 3 .

40. Count the plaques. This can be done by holding the plates against the light. Alternatively, remove agarose overlay and stain with crystal violet. To stain, cover the cells with a minimal amount of crystal violet solution for $\sim 15 \mathrm{~min}$. Rock plates if necessary to ensure even coverage. Gently wash off the crystal violet stain with water. Once fixed, stained, and dried, store plaques indefinitely for future analysis.

41. Calculate viral titer in PFU/mL: Average count of duplicate well $\times$ Dilution factor $\times(1000 / 150)=\mathrm{PFU} / \mathrm{mL}$ (multiply lung homogenate counts by 2 to give total viral load, as lungs were taken and homogenized in $2 \mathrm{~mL} \mathrm{RPMI}$ ).

1. Allow a little extra for pipetting wastage when making up antibody cocktails. Keep on ice and protect from light (e.g., with aluminum foil). Make up cocktails in FACS buffer, but for the intracellular stains these should be made up in Perm Wash buffer containing $0.1 \%$ Saponin.

2. Congenic markers could be reversed or other markers are used as appropriate to the mouse strains being used and to the specific experimental set-up.

3. Biological Hazards $-S$. Typhimurium BRD509 is a risk group 2 pathogen. Influenza A virus-PR8-strain $(\mathrm{HINl})$ is a lab adapted strain of IAV virus. Work should be risk assessed and we recommend controls that include but are not restricted to the following: Lab coat, safety glasses, and gloves should be worn when performing this protocol. Gloves should be removed or sterilized before exiting the biohazard hood. Solutions of Lysol (200 ppm) or hypochlorite (5000 ppm) should be accessible in case of a spill.

4. Decontaminate all pipette tips in $1 \%$ Virkon when working in the biohazard cabinet. After use, the biohazard hood should be 
decontaminated by wiping down with $70 \%$ ethanol and by UV sterilization for 15 min before any further use. All waste and its container must be disposed as hazardous waste.

5. Pulmonary MAIT cells can be expanded using any source of 5-OP-RU and an appropriate TLR agonist [15, 17]. A systematic assessment of effective TLR agonists has shown strong MAIT cell expansion 7 days after intranasal inoculation with 76 pmol 5-OP-RU on days 1,2 , and 4 in combination with a single dose of agonist on day 1 to TLR3 (high molecular weight poly I:C), TLR4 (lipopolysaccharide from E. coli), TLR2/6 (FSL-1 (Pam2CGDPKHPKSF)), or TLR9 (CpG ODN1826), but not with agonists of TLRl/2 (Pam3CSK4), TLR2, TLR5, TLR7 [3]. Each inoculum should be instilled in $50 \mu \mathrm{L}$ PBS. However, the requirement for accurate repeated inoculations can introduce significant variability in MAIT cell expansion. A simple, less costly on reagents and time, and equally effective, if not more so, is a single intranasal inoculation with $S$. Typhimurium BRD509 in $50 \mu \mathrm{L}$ PBS.

6. Growth of bacteria is estimated by measuring the culture in a spectrophotometer at $600 \mathrm{~nm}$. To do so fill a cuvette with fresh LB media, place in spectrophotometer, and use this to blank. Then take $500 \mu \mathrm{L}$ of bacteria-containing broth and measure optical density. To calculate the inoculum dose, use the estimate that an O.D. $600 \mathrm{~nm}$ of $1=5 \times 10^{8} \mathrm{CFU} / \mathrm{mL}$.

7. Accurate intranasal inoculation depends critically on the depth of anesthesia. Administer isoflurane and observe breathing pattern until respiratory rate has decreased to approximately 100 breaths $/ \mathrm{min}$ and is deep and relaxed. If insufficient depth is achieved mice will sneeze. If depth of anesthesia is too great (further slowing of respiratory rate and very deep breaths), then mice tend to spontaneously breath-hold and again, volume inhaled will be unreliable. Place $50 \mu \mathrm{L}$ of inoculum onto the left nasal opening (if user is right-handed) using a P200 pipette, gradually ejecting the $50 \mu \mathrm{L}$ over a few breath cycles until all has been inspired.

8. Intranasal $S$. Typhimurium is well tolerated in immunocompetent strains such as $\mathrm{C} 57 \mathrm{BL} / 6$ and BALB/c with less than $5 \%$ of animals showing minor signs of illness (ruffled hair) within 1-2 days after infection. These animals fully recover after days 3-5. The lethal dose of $S$. Typhimurium BRD509 is $>2 \times 10^{7}$ $\mathrm{CFU} /$ mouse (wild-type C57BL/6 adult). Caution should be used in immunocompromised strains in which pilot experiments should be performed to confirm optimal safe inocula.

9. This MAIT cell expansion is long-lived [15], so donor mice can be prepared several weeks in advance. 
10. The lungs can conveniently be chopped up using the back of an upturned Petri dish. Using fine forceps lift lungs from the RPMI in which they have been transferred, gently blot off excess liquid with tissue paper and place on the Petri dish. Use a large curved scalpel blade to repeatedly chop through the lungs at multiple angles for at least $60 \mathrm{~s}$ each until a very fine and homogeneous texture is achieved.

11. Typically this method will yield $1.5 \times 10^{6}$ pulmonary MAIT cells per mouse, so multiple mice may be required as donors, depending on the requirements of the experiment.

12. This will be sufficient for lungs from 8 mice.

13. If transferring cells into a $\operatorname{Rag} 2^{-/-} \gamma \mathrm{C}^{-/-}$mouse then low frequencies of "contaminating" conventional $\mathrm{CD}^{+}$or $\mathrm{CD}^{+}$ $\mathrm{T}$ cells tend to expand more rapidly than the MAIT cells and produce artifacts (not obvious for other T-cell-deficient mice, e.g., TCR $\alpha^{-/-}$or RAG $2^{-/-}$). As many MAIT cells are doublenegative, it is possible to prevent this effect by repeated injections with T-cell-depleting anti-CD4 and anti-CD8 antibodies [17].

14. The PR8 strain of influenza virus is highly virulent in mice and only low inoculate are tolerated. The exact inoculum required for each experimental system will need to be carefully determined depending on the exact strain and batch of PR8 and the strain of mice, and local welfare and monitoring requirements. In our hands $\mathrm{C} 57 \mathrm{BL} / 6$ mice receiving $100 \mathrm{PFU}$ of $\mathrm{A} / \mathrm{PR} / 8 /$ 34 AF18 WCN experienced severe pneumonia in mice, characterized by parenchymal necrosis and infiltrates of macrophages, lymphocytes, and neutrophils, with 10-25\% mortality due to welfare concerns or weight loss $>20 \%$.

15. Virally infected mice experience a transient viral illness with transient. Viral titers peak at day 3 . Weight loss peaks at day 5-7 post infection, and there would be a significant weight gain expected by day 8 and resolving by day 10 post infection. Typically mice should be monitored and/or weighed daily for signs of ill health such as ruffled fur, hunched-up appearance, gait abnormalities, lethargy and loss of body condition for 10 days after challenge or till all the symptoms disappear and body weight returns to pre-challenge level. Monitoring can then return to twice weekly.

16. For many homogenization probes a wide tube is needed, such as the sterile, capped, round-bottom polypropylene tubes which are available.

17. The homogenizer generates a lot of heat at the probe tip. Samples should be kept on ice before and after homogenization, and the probe should be intermittently rested to cool down in ice-cold $\mathrm{EtOH}$ between groups of 5 or 10 samples. 
Between samples or groups of samples clean the probe by running briefly in EtOH and then rinsing briefly in HBSS. Often connective tissue will clog the probe and this can be removed with large forceps. After use the probe tip should be sterilized.

18. Only approximately $2 / 7$ of one lung is needed for intracellular cytokine staining, so the other lung, or other sections of lung, can be saved for viral titer estimation, histology, or other assays if required.

19. To clarify terminology there are two lungs in each animal, so "one lung" refers to all the 2 or 3 lobes in a single hemithorax. Due to the presence of the heart on the left side, the left lung is smaller with only 2 lobes.

20. Using a spectrophotometer saves time for large numbers of samples. To do this resuspend cell pellet in 1-2 mL PBS (or adjust according to pellet size/counts). Select O.D.600nm. Blank cuvette with $1 \mathrm{~mL}$ FACS wash/PBS. Measure O. D. $600 \mathrm{~nm}$ with $200 \mu \mathrm{L}$ samples $+800 \mu \mathrm{L}$ PBS $(5 \times)$. Calculate the number of cells: this is a simple linear relationship between O.D. and the number of cells, which can be derived by measuring a few cell counts in parallel on both the hemocytometer and the spectrophotometer.

21. An alternative is to resuspend the entire pellet in $700 \mu \mathrm{L}$ of FACS buffer and take $200 \mu \mathrm{L}$ into 96-well plate: this should contain approximately $1-1.5 \times 10^{6}$ cells, appropriate for staining.

22. To avoid using multiple filters, it is possible to buy large sheets of $40 \mu \mathrm{m}$ mesh. A single rectangle can be cut which covers a whole plate. Using this, multiple cells can be pipette simultaneously with a multichannel pipette.

23. In round-bottom plates cells may clump so consider using flatbottom plate for the stimulation step, especially if doing further steps in FACS tubes rather than staining in plate format.

24. While surface markers can be measured on the intracellularly stained cells, the most accurate measurement of MAIT cell frequencies will be obtained from immediate surface staining prior to stimulation, due to activation-induced downregulation of the TCR.

25. If cells are not to be acquired immediately, then they can instead be resuspended in $100 \mu \mathrm{L}$ of fixation buffer and stored at $4{ }^{\circ} \mathrm{C}$ until required.

26. This may differ depending on virus and mouse strains.

27. The overlay media will start setting so proceed to the following steps quickly. Overlay media can be made in batches to assist with that. 
Acknowledgments

This work was funded by grants to T.S.C.H. from the Wellcome Trust $(104553 / \mathrm{z} / 14 / \mathrm{z}, 211050 / \mathrm{Z} / 18 / \mathrm{z})$ and Project Grants 1062889 and 1120467 and Program Grant 1113293 from the National Health and Medical Research Council of Australia. B.W. was supported by the Royal Society (IE160540). A.J.C. is supported by a Future Fellowship from the Australian Research Council, FT1600100083. The research leading to these results has received funding from the People Programme (Marie Curie Actions) of the European Union's Seventh Framework Programme (FP7/2007-2013) under REA grant agreement number 608765. The content represents only the authors' views and not those of the European Commission. HW was supported by a Melbourne International Engagement Award (University of Melbourne).

\section{References}

1. Eckle SB, Corbett AJ, Keller AN et al (2015) Recognition of vitamin B precursors and byproducts by mucosal associated invariant $\mathrm{T}$ cells. J Biol Chem 290:30204-30211

2. Godfrey DI, Uldrich AP, Mccluskey J et al (2015) The burgeoning family of unconventional T cells. Nat Immunol 16:1114-1123

3. Hinks TSC, Marchi, E, Jabeen, $M$ et al (2019) Activation and in vivo evolution of the MAIT cell transcriptome in mice and humans reveals tissue repair functionality. Cell Reports 28 (12):3249-3262.e5

4. Kjer-Nielsen L, Patel O, Corbett AJ et al (2012) MRl presents microbial vitamin B metabolites to MAIT cells. Nature 491:717-723

5. Hinks TS, Zhou X, Staples KJ et al (2015) Innate and adaptive $\mathrm{T}$ cells in asthmatic patients: relationship to severity and disease mechanisms. J Allergy Clin Immunol 136:323-333

6. Rahimpour A, Koay HF, Enders A et al (2015) Identification of phenotypically and functionally heterogeneous mouse mucosal-associated invariant T cells using MRl tetramers. J Exp Med 212:1095-1108

7. Tsukamoto K, Deakin JE, Graves JA et al (2013) Exceptionally high conservation of the MHC class I-related gene, MRl, among mammals. Immunogenetics 65:115-124
8. Corbett AJ, Eckle SB, Birkinshaw RW et al (2014) T-cell activation by transitory neo-antigens derived from distinct microbial pathways. Nature 509:361-365

9. Patel O, Kjer-Nielsen L, Le Nours $J$ et al (2013) Recognition of vitamin B metabolites by mucosal-associated invariant $\mathrm{T}$ cells. Nat Commun 4:2142

10. Ussher JE, Bilton M, Attwod E et al (2014) CDl61++ CD8 + T cells, including the MAIT cell subset, are specifically activated by IL-12 +IL-18 in a TCR-independent manner. Eur J Immunol 44:195-203

11. Van Wilgenburg B, Scherwitzl I, Hutchinson EC et al (2016) MAIT cells are activated during human viral infections. Nat Commun 7:11653

12. Wilgenburg BV, Loh L, Chen Z et al (2018) MAIT cells contribute to protection against lethal influenza infection in vivo. Nat Commun 9:4706

13. Loh L, Wang Z, Sant $S$ et al (2016) Human mucosal-associated invariant $\mathrm{T}$ cells contribute to antiviral influenza immunity via IL-18dependent activation. Proc Natl Acad Sci U S A 113:10133-10138

14. Hoiseth SK, Stocker BA (1981) Aromaticdependent Salmonella typhimurium are non-virulent and effective as live vaccines. Nature 291:238-239 
15. Chen Z, Wang H, D'souza C et al (2017) Mucosal-associated invariant T-cell activation and accumulation after in vivo infection depends on microbial riboflavin synthesis and co-stimulatory signals. Mucosal Immunol 10:58-68

16. Reantragoon R, Corbett AJ, Sakala IG et al (2013) Antigen-loaded MRl tetramers define
$\mathrm{T}$ cell receptor heterogeneity in mucosalassociated invariant $\mathrm{T}$ cells. J Exp Med 210:2305-2320

17. Wang H, D'souza C, Lim XY et al (2018) MAIT cells protect against pulmonary Legionella longbeachae infection. Nat Commun 9:3350

Open Access This chapter is licensed under the terms of the Creative Commons Attribution 4.0 International License (http://creativecommons.org/licenses/by/4.0/), which permits use, sharing, adaptation, distribution and reproduction in any medium or format, as long as you give appropriate credit to the original author(s) and the source, provide a link to the Creative Commons license and indicate if changes were made.

The images or other third party material in this chapter are included in the chapter's Creative Commons license, unless indicated otherwise in a credit line to the material. If material is not included in the chapter's Creative Commons license and your intended use is not permitted by statutory regulation or exceeds the permitted use, you will need to obtain permission directly from the copyright holder. 